TEME, г. XLIV, бр. 4, октобар - децембар 2020, стр. 1351-1367

Оригинални научни рад https://doi.org/10.22190/TEME190404080I

Примљено: 4. 4. 2019.

UDK 159.944.4:331.1

Ревидирана верзија: 13. 1. 2019.

331.44

Одобрено за штампу: 1. 12. 2020.

\title{
DO RECRUITERS IN SERBIA FACE BURNOUT? THE IMPACT OF DEMOGRAPHIC FACTORS, DEADLINES AND WORK PRESSURE ON BURNOUT PRESENCE
}

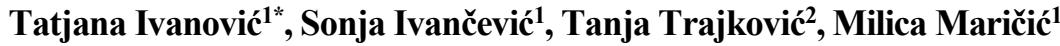 \\ ${ }^{1}$ University of Belgrade, Faculty of Organizational Sciences, Belgrade, Serbia \\ ${ }^{2}$ ICL Services and Solutions, Belgrade, Serbia \\ *tatjana.ivanovic@fon.bg.ac.rs
}

\begin{abstract}
Burnout syndrome represents one of the most serious disorders in contemporary work environment. One of the professions that did not receive much attention in the scientific research of burnout is that of recruiters, even though literature shows that recruiters face work-related stress on a daily basis, which can often lead to burnout among this group of employees. The aim of this paper is to attempt to identify whether and to what extent burnout is present among recruiters in Serbia (both in-house recruiters and those employed in recruiting companies and agencies) and to reveal the determinants which influence the possibility of burnout occurrence among this group of workers. The most frequently examined variables affecting burnout in other professions were analyzed: age, work experience, marital status, strict deadlines and work pressure. Copenhagen Burnout Inventory (CBI) was used to measure the level of burnout. The results obtained by a quantitative research using questionnaires conducted among 100 recruiters in Serbia have shown that recruiters in Serbia face burnout to an extent (overall burnout, individual, workrelated and client-related burnout), while all examined variables (except employee's age) were found to have statistically significant impact on burnout presence among recruiters. What adds value to this paper is the fact that the amount of burnout studies conducted in Serbia in general is scarce and mostly focused on helping professions. The research has a practical purpose to help companies and human resource departments create appropriate burnout prevention training programmes targeted for recruiters.
\end{abstract}

Key words: $\quad$ burnout, burnout syndrome, recruiter, recruitment, Copenhagen Burnout Inventory, CBI. 


\title{
ДА ЛИ СЕ РЕГРУТЕРИ У СРБИЈИ СУОЧАВАЈУ СА СИНДРОМОМ ИЗГАРАЫА? УТИЦАЈ ДЕМОГРАФСКИХ ФАКТОРА, РОКОВА И ПРИТИСКА НА ПОСЛУ НА ПОЈАВУ ИЗГАРАЫА
}

\begin{abstract}
Апстракт
Синдром изгарања представља један од најозбиљнијих поремећаја у савременом радном окружењу. Регрутери су једна од професија којој није посвећено много пажње у научним истраживањима, иако се у литератури наводи да се регрутери свакодневно суочавају са стресом на раду, који често може довести до појаве синдрома изгарања ове групе запослених. Циљ овог рада је да покуша да идентификује да ли је и у којој мери синдром изгарања присутан код регрутера у Србији (код оних који регрутују кандидате за свог послодавца и код оних који су запослени у агенцијама и регрутују кандидате за клијенте) и да открије факторе који утичу на могућност појаве синдрома изгарања код ове групе запослених. Анализиране су варијабле које најчешће утичу на изгарање у другим професијама: старост, радно искуство, брачни статус, стриктни рокови и притисак на раду. Копенхаген-упитник (CBI) за мерење синдрома изгарања коришћен је за мерење степена изложености синдрому изгарања. Резултати добијени емпиријским истраживањем путем упитника који је попунило 100 регрутера у Србији показали су да се регрутери у Србији у извесној мери суочавају са синдромом изгарања (укупно изгарање, изгарање на личном нивоу, изгарање у вези са послом, изгарање у вези са клијентима), а показало се да све испитиване варијабле (осим старости запосленог) имају статистички значајан утицај на присуство синдрома изгарања код регрутера. Посебна вредност рада огледа се у чињеници да је број истраживања у вези са синдромом изгарања у Србији веома мали и да су се аутори у досадашњим истраживањима углавном бавили изгарањем код помажућих професија. Ово истраживање има и практични допринос - да помогне компанијама и одељењима за људске ресурсе да осмисле одговарајуће програме обуке за превенцију синдрома изгарања код регрутера.
\end{abstract}

Кључне речи: изгарање, синдром изгарања, регрутер, регрутовање, СВI.

\section{INTRODUCTION}

Since the mid-seventies when Freudenberger (1974) introduced the term burnout into psychology, the number of research examining burnout syndrome has been on the increase. One of the reasons is the everincreasing pace of life and the consequent rise of reported work related stress (Smith, 2019). On the other hand, the findings have proven that burnout syndrome does not exist only in the helping professions, as it was previously thought, but also among the professionals of all walks of life (Schaufeli, Maassen, Bakker \& Sixma, 2011).

Nevertheless, one of the professions that has not received much attention in the scientific research of burnout is that of recruiters. Moreover, to the knowledge of the authors of this paper, no study has examined the burnout process as it applies to the profession of recruiters. Contrary to that, there is a lot of professional literature that analyzes the burnout syndrome among recruiters (Savage, 2013; Weeks, 2017; Zoromski, 
2007). Studies show that the recruiting sector is one of the most stressful working environments in the contemporary workplace (Berry, 2008). Factors that are thought to contribute to the high level of recruiters' stress are a large number of external and internal clients, role conflicts, pressure from both clients and managers, strict deadlines, constant rejections in a highly competitive market, as well as their personal characteristics (Sorgaard, Ryan, Hill \& Dawson, 2007; Torrington, Hall \& Taylor, 2011).

Having all this in mind, the aim of this paper is to attempt to identify the extent to which recruiters (in-house as well as those employed in recruiting companies and agencies) are exposed to burnout syndrome and to reveal the determinants which influence the possibility of burnout among this group of workers. What adds value to this study is the fact that the amount of burnout study conducted in Serbia in general is scarce and mostly focused on helping professions. The research has a practical purpose to help companies and human resource sectors create appropriate burnout prevention training programmes targeted for recruiters.

\section{LITERATURE REVIEW}

\section{Burnout Syndrome}

Burnout is typically defined as a state of complete emotional, mental and physical exhaustion caused by excessive and prolonged occupational stress (Ivančević, Vaci \& Nišić, 2016). Freudenberger (1974) described it as a gradual loss of idealism, energy, sense of purpose and goals, which is usually experienced among workers in helping professions, and presents a direct consequence of the conditions they work in and is their response to a high level of chronic stress. In the decade that followed, Christina Maslach conducted numerous studies on burnout and concluded that it is a cluster of symptoms that appear in the situation of prolonged stress in the workplace and is characterized by three dimensions: emotional exhaustion, depersonalisation and diminished personal accomplishment (Maslach, 1982). Emotional exhaustion refers to the state or feeling of a particular emotional extension that is accompanied with physical exhaustion (Maslach and Jackson, 1979; Savicki and Cooley, 1982). Depersonalisation is described as the developing of a specific negative attitude towards coworkers and clients, manifested through cynicism, indifference and lack of concern for the people in the workplace and gradual isolation and distancing from them (Maslach and Jackson, 1979). Diminished personal accomplishment is defined as a subjective feeling of personal incompetence and lack of success at work (Maslach and Jackson, 1979). 


\section{Recruitment and Potential Stress Factors in the Recruiting Process}

Strategically and practically speaking, one of the most important functions of human resource management is recruitment. It precedes the selection process and consists of the activities and policies that are conducted with the aim of identification and attraction of prospective employees (Breaugh \& Starke, 2000). Recruitment may be conducted internally or it can be outsourced to specialized companies or professionals.

Recruiters face a lot of challenges daily, first of all, in connection to the workload. They have to source candidates, distribute job advertisements, go through numerous application forms and assess applicants, but also conduct a number of interviews on a daily basis (Melanthiou, Pavlou \& Constantinou, 2015; Torrington et al., 2011). Due to the highly competitive market, the attraction of new employees increasingly demands certain sales-related qualities of recruiters who consequently face a variety of new challenges (Lievens, van Dam \& Anderson, 2002; Weeks, 2017) and experience additional work pressure. Some of those challenges include being able to bear constant rejections without allowing them to affect their emotions negatively. Another thing that has made the recruiters' job more complex and demanding in the recent decades is the soaring number of social media and new technologies, which can also present a distraction. Despite the fact that the Internet enabled online recruitment and dramatically enlarged the number of potential clients, it has also made the job of extracting important information from such an enormous pool of data more difficult. It has also forced recruiters to be faster and more responsive, and do more work for the same amount of time decreasing simultaneously the time needed for rest.

In addition, it should be emphasized that another factor contributes to the recruiter's potential stress and that is the human factor. The recruiter's job depends, on one hand, on the will of candidates and clients, and on the other hand, on the will of a hiring manager and other managers in the company (Weeks, 2017). The change of will of any of them in any stage of the recruiting process can make the recruiter's work futile (Weeks, 2017).

Recruiters often face short deadlines, long work hours, lack of benefits and the appropriate trainings which can all lead to burnout and the consequent turnover (Oh \& Pizam, 2008). For those reasons it is important to examine the level of burnout of professional recruiters and the impact of certain variables to its occurrence. Since this study represents a pioneer research of burnout syndrome among recruiters (in Serbia), some of the most commonly examined variables have been chosen for the analysis. The goal of it should primarily be to provide guidelines for structuring effective burnout prevention strategies thus preventing recruiters' turnover and maintaining recruiters' health. 


\section{Relationship Between Age, Work Experience, and Burnout}

The very pioneer of burnout scientific research, Christina Maslach, and her coworkers claim that of all the demographic variables that have been studied, age is the one that has most consistently been related to burnout (Maslach, Schaufeli \& Leiter, 2001). It is added that burnout level is usually reported to be higher among younger employees, usually bellow the age of 30. They also mention that work experience, as another variable, is frequently negatively correlated to burnout, higher levels of which being more present earlier in employees' career. However, they state that those findings should be taken with caution since the reasons behind them were not examined thoroughly (Maslach et al., 2001).

One of the most comprehensive studies that examined the correlation between age and work experience and burnout is Brewer \& Shapard's (2004) study: 'Employee Burnout: A Meta-Analysis of the Relationship between Age or Years of Experience'. They performed a metaanalysis on the data that were extracted from 34 studies and concluded that there is a significant though not large negative correlation between age and burnout, and the very same was proven for work experience in a field and burnout (Brewer \& Shapard, 2004). Nevertheless, their study also showed that the results differed in correlation to specific occupational group (social workers, educators, nurses, clergy and other occupations). Recruiters were not included in the study.

In the study 'Burnout in the general population' (Ahola et al., 2006) it was shown that burnout seemed to slightly increase with age, mostly among human resource workers. Another inclusive study was carried out in Finland, testing the relation between age and burnout in the adult working population encompassing all fields of work activity. It showed that burnout both decreases and increases with age, reporting the highest levels of it in the youngest and the oldest working women, as well as the middle aged working men (Ahola, Honkonen, Virtanen, Aromaa \& Lönnqvist, 2008).

Other studies examined the relation between age and burnout within particular occupations. Foreman's (1996) study on clergy showed that those between the age of 30 and 39 experienced more burnout than those younger than them, but that burnout level also decreased with the following decades. Antoniou, Polychroni \& Vlachakis (2006) found that younger teachers in Greece experienced higher level of burnout in terms of emotional exhaustion and disengagement from profession, while older teachers experienced higher level of stress when lacking 'government support'. Byrne (1991) also suggested that younger and less experienced teachers experienced higher level of burnout. 


\section{Marital Status and Burnout}

Since the beginning of burnout research, marital status of employees has been of one the examined variables. Maslach and Jackson's (1985) earlier study showed a consistent level of lower burnout presence among the employees who were married than among those who were not, emphasizing the importance of family responsibilities, and adding further, more drastic findings that childless employees showed higher levels of burnout than those who had children. In their later study, Maslach et al. (2001) once again found evidence that those who were unmarried (particularly men) seemed to be more susceptible to burnout in comparison to those who were married. In their opinion, employees who were single seemed to experience even higher level of burnout than the divorced. In addition, Ahola et al. (2006) reported in their study that being single, divorced or widowed carried a potential risk of burnout for men.

\section{Deadlines and Work Pressure, and Burnout}

The consequence of a chronic exposure to stress is the reduced responsiveness and the blockage of the HPA (Hypothalamic-PituitaryAdrenal axis) axis signal. Its result is the diminished secretion of cortisol and adrenaline needed for the body to produce energy, and it appears in the third stage of burnout which is fully named 'Adrenal Burnout Syndrome'. Thus, it is easy comprehend why some of the first researchers of this syndrome, Maslach and Jackson (1985), found that work pressure is among those organizational job stressors that are strongly associated with burnout, its emotional exhaustion component in particular. Constable and Russell (1986) also found that work pressure is one of the major determinants of burnout among nurses. Similarly, Sethi, Barrier \& King (1999) showed that unrealistic deadlines are among the main reasons for burnout among IT professionals. Pawlowski, Kaganer \& Cater (2004) also examined unrealistic deadlines as one of burnout predictors. For those reasons and the synonymous conception of stress and the state of being 'under pressure', we found it important to analyze the relation of these two variables and the recruiters' burnout.

To our knowledge no research examining the impact of age, work experience, marital status, unrealistic deadlines or work pressure of recruiters on burnout has been conducted so far. Having in mind the stated, the following hypotheses were defined:

Hypothesis 1: Recruiters suffer from a high level of burnout.

Hypothesis 2: Age has an impact on recruiter burnout.

Hypothesis 3: Work experience in recruiting has an impact on recruiter burnout.

Hypothesis 4: There is statistically significant difference in the level of recruiter burnout regarding their marital status. 
Hypothesis 5: There is statistically significant difference in the level of recruiter burnout regarding the existence of strict deadlines.

Hypothesis 6: Work pressure affects recruiter burnout.

\section{METHOD}

We conducted an online survey from February until March 2019. The survey was distributed via email. Afterwards, the statistical analysis was performed using SPSS 22. The survey consisted of questions regarding four main areas: Demographic information and the Copenhagen Burnout Inventory: Personal burnout, Work-related burnout and Client-related burnout. The first section of the survey asked the respondents basic demographic information which included gender, age, highest completed degree, marital status, nationality, country in which they currently work in, and the questions related to work experience. The following three sections were related to Personal burnout, Work-related burnout, and Client-related burnout. The questions used to measure the three types of burnout are from the official CBI (Kristensen, Borritz, Villadsen \& Christensen, 2005). Personal burnout, Work-related burnout, and Client-related burnout are measured using six, seven and six items respectfully. All of them are measured on a Likert scale from 1 (Never/almost never/to a very low degree) to 5 (Always/to a very high degree). Afterwards, the values have been scored on a scale 0 to 100 . Namely, the values have been recoded: 1 scoring 0,2 scoring 25,3 scoring 50, 4 scoring 75 , and 5 scoring 100 .

\section{Sample}

After conducting the survey, we collected 100 responses. It should be emphasized that companies in Serbia mostly do not contain the position of a recruiter, and if they do, the number of them is usually only one or two. For this reason, we presume that the total number of 100 participants in this study is quite representative for Serbia. We assessed 77 female recruiters who make $77.0 \%$ of the sample, and 23 male recruiters $(23.0 \%)$. The disproportion in the gender of the respondents can be noted. Nevertheless, such a result could have been expected as positions in HR are preferred by females (Olson, Hanson Frieze \& Good, 1987). The mean age of the respondent is 33.41 with a standard deviation of 6.997 . The age of the respondents ranges from 22 to 53 , with the median of 32. This indicates that half of the respondents is younger than 32 . We can conclude that we have covered the part of the younger recruiter population. When it comes to the highest education level completed, almost half of the respondents, $48 \%$ of them, has a masters' degree, followed by $44 \%$ who have the bachelors' degree. The remaining respondents achieved high school, $\mathrm{PhD}$, or specialization. According to the marital status, $36 \%$ of them are married, $35 \%$ are in a relationship, while the rest are single. The mean number of 
years of experience in recruiting is 6.04 with the standard deviation of 4.726. The median years of experience is 4.5 which indicates that the respondents covered by the research have experience in recruiting.

\section{RESULTS AND DISCUSSION}

As mentioned, several additional questions we inserted in the survey. The first was related to whom the respondent recruits the candidates for. The question had three levels: recruiting for clients' needs, for the company's needs and both. A little more than half of the respondents (53\%) recruit for company's needs, $26 \%$ recruit for clients and the rest recruit for both. Therefore, $47 \%$ of the respondents were eligible for calculating the Clientrelated burnout. Next, to differentiate the respondents regarding the existence of strict deadlines for filling the positions we asked them whether or not they have deadlines and what they think of them. The question was "The deadlines for filling the position are" while the possible answers were "I do not have deadlines, Deadlines are realistic and achievable, and Deadlines are unrealistic and non-achievable". Finally, we wanted to measure the frequency of working under pressure. The question was "How often do you feel work pressure", and it was measured on a 5-point Likert scale from 1 (Never/very rarely) to 5 (Always/very often).

To additionally inspect the scales used in the research, we conducted the scale reliability analysis using the Cronbach's alpha (Cronbach, 1951). Scale reliability can be described as the level up to which all the items in a scale measure the same concept (Tavakol \& Dennick, 2011). It takes values from 0 to 1 , where 1 means complete internal consistency, and 0 means complete inconsistency. The values of Cronbach's alpha per scale are given in Table 1. As it can be observed it varies from 0.957 (Client-related burnout) to 0.869 (Work-related burnout). As the recommended threshold is 0.7 (Peterson, 1994), we can conclude that all the scales are consistent.

Table 1. Cronbach's alpha per construct

\begin{tabular}{lccc}
\hline Construct & $\begin{array}{c}\text { Personal } \\
\text { burnout }\end{array}$ & $\begin{array}{c}\text { Work-related } \\
\text { burnout }\end{array}$ & $\begin{array}{c}\text { Client-related } \\
\text { burnout }\end{array}$ \\
\hline Cronbach's alpha & 0.926 & 0.869 & 0.957 \\
\hline
\end{tabular}

In the next stage, the values of each type of burnout were obtained. As suggested by the official CBI, the values of each burnout were calculated using the simple mean of the items. Above that, the overall burnout was obtained as the simple mean of the Personal, Work-related, and Clientrelated burnout. In the next paragraphs we will provide basic descriptive statistics for the three observed constructs and the overall burnout.

Comparing the mean values of the three types of burnout, we observe that the Client-related burnout has the highest mean (55.496), followed 
by Personal burnout (42.875). This would indicate that $47 \%$ of the sampled recruiters who work with clients sometimes or to a degree experience client-related burnout. Interestingly, the respondents experienced the lowest mean on Work-related burnout of 39.5. The standard deviations of the three constructs show that the values of Client-related burnout vary more than the scores of the remaining two types of burnout, 4.063 compared to 2.252 (Personal burnout) and 2.237 (Work-related burnout). The mean overall burnout is 43.685 meaning that the respondents are close to "sometimes experiencing burnout". The standard deviation is 2.219 which indicates that the results are stable and consistent. The box-plots of the three constructs and the overall burnout score are given in Figure 1. The box-plot for Personal burnout shows that there are several outliers, precisely there are three respondents who are experiencing extreme personal burnout. Other types of burnout and overall burnout showed no outliers. Comparing the medians, the median of the Client-related burnout is the highest. The same accounts for the interquartile range. Therefore, it can be concluded that there is a smaller level of agreement on the issue of client-related burnout and that among the respondents who have clients, this type of burnout is noticeable.

Thus, the Hypothesis 1 is not confirmed. The burnout scores in the present study were above the average scores found by Kristensen et al. (2005) which were 35.9, 33.0, and 30.9 for personal, work-related and client-related burnout, respectively, across 15 jobs. In comparison to other examined occupations in Serbia, e.g. translators, lectors, coordinator and managers employed on the television (Trajković, Ivanović \& Ivančević, 2019), teachers and special education therapists (Ivančević \& Kiković, 2017), Serbian recruiters suffer from a much lower degree of burnout syndrome, which is also in contrast to the Hypothesis 1. 


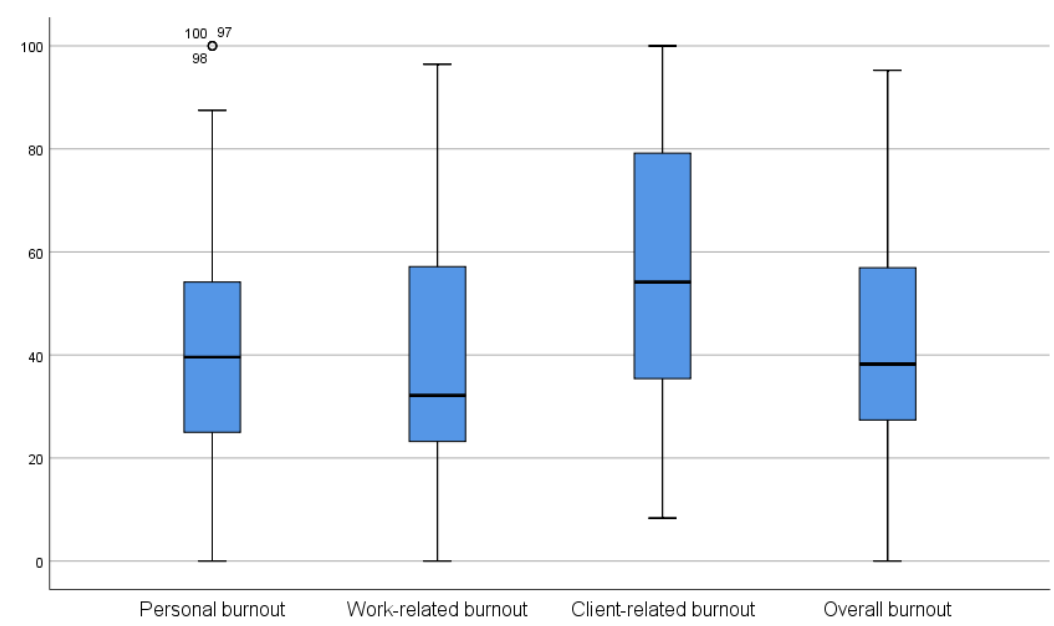

Figure 1 Box plot comparing the values of the three types of burnout and overall burnout

Hypothesis 2 and 3 were explored using the Pearson's correlation coefficient between Age and Work experience on one side and burnout types on the other. The obtained correlation coefficients are given in Table 2. When it comes to the impact of Age on burnout, we can conclude that there is no statistically significant impact. Thus, Hypothesis 2 is not confirmed. This finding is contrary to the findings of Maslach et al. (2001), Brewer and Shapard (2004), Ahola et al. (2006), Ahola et al. (2008) who found that employees' age has influence on the presence of burnout syndrome.

Table 2. Pearson's correlation coefficient between Age and Work experience and burnout

\begin{tabular}{lcccc}
\hline Construct & $\begin{array}{c}\text { Personal } \\
\text { burnout }\end{array}$ & $\begin{array}{c}\text { Work-related } \\
\text { burnout }\end{array}$ & $\begin{array}{c}\text { Client-related } \\
\text { burnout }\end{array}$ & $\begin{array}{c}\text { Overall } \\
\text { burnout }\end{array}$ \\
\hline Age & -0.111 & -0.028 & 0.039 & -0.040 \\
Work experience & 0.121 & $0.232^{*}$ & 0.209 & $0.235^{*}$ \\
\hline \multicolumn{5}{c}{$\mathrm{p}<0.05$}
\end{tabular}

Contrary to Age, Work experience has an impact on Work-related burnout and the Overall burnout. Pearson's correlation coefficients of 0.232 and 0.235 , although weak, indicate that the more experienced recruiters are more prone to work-related burnout and overall burnout. Thus, Hypothesis 3 is confirmed. However, contrary to what was expected, the study has shown that work experience is positively correlated to burnout, indicating that more experienced recruiters are more susceptible to work-related and overall burnout. This finding differs from the results 
of Brewer and Shapard's (2004) research, as they found a significant negative correlation between work experience in the field and burnout.

For investigating whether there is difference in burnout depending on the marital status, we used analysis of variance (ANOVA). Significant differences have been observed for Personal burnout, Work-related burnout, and Overall burnout, providing support for Hypothesis 4. Therefore, the more detailed insights are presented in Table 3. Beside mean and standard deviation per group and the value of the statistics, we conducted post hoc tests to inspect among which groups there is a statistically significant difference. Levene's test showed that the variances are equal between different groups of Personal, Work-related and Overall burnout $(\mathrm{p}<0.05)$ in all three cases. Therefore, the chosen post hoc test was the LSD (Least significant difference) test as this test requires equal variances (Day \& Quinn, 1989).

A pattern of differences can be observed. Regarding burnout, the single respondents are more prone to burnout than their colleagues who are married or in a relationship. The most drastic difference is observed for Overall burnout, where the mean for single respondents is 52.801 compared to 37.709 (In a relationship) and 42.151 (Married).

Table 3. Parameter values of burnout types for different marital status, the significance of the ANOVA test, and the post hoc test

\begin{tabular}{llccc}
\hline Construct Groups & Mean \pm SD & ANOVA & Post hoc \\
\hline \multirow{2}{*}{$\begin{array}{l}\text { Personal } \\
\text { burnout }\end{array}$} & Married & $39.699 \pm 19.530$ & & Married < Single \\
& Single & $51.724 \pm 22.258$ & $3.315^{*}$ & In a relationship < Single \\
\hline Work- & Married & $38.789 \pm 18.133$ & & Married < Single \\
related & In a relationship & $32.653 \pm 22.837$ & $4.356^{*}$ & In a relationship < Single \\
burnout & Single & $48.645 \pm 24.079$ & & Married < Single \\
\multirow{2}{*}{$\begin{array}{l}\text { Overall } \\
\text { burnout }\end{array}$} & Married & $42.151 \pm 19.064$ & & \multirow{2}{*}{ In a relationship } \\
& Single & $52.709 \pm 23.085$ & $4.032^{*}$ & In a relationship < Single \\
\hline & & ${ }^{*} \mathrm{p}<0.05$ &
\end{tabular}

The study has shown that marital status affects recruiter burnout in the manner that recruiters who are married or in a relationship showed lower risk of developing burnout. These findings are aligned with the results of Ahola et al. (2006) who concluded that not being married increases the potential risk of burnout. Interpreting the results of Maslach and Jackson's (1985) study, Greenglass and Burk (1988) say that family life teaches people to handle critical and interpersonal situations at work more effectively, gaining practice in problem solving and conflict resolution within family framework. They also add the importance of probable support that 
the family provides for its members, thus helping them cope with workrelated stress better (Greenglass \& Burke, 1988).

To accept or reject the Hypothesis 5, we compared the values of different types of burnout among the recruiters depending on their attitude towards deadlines. As only 6 respondents said they do not have deadlines, we focused on the comparison of the respondents who have deadlines. Most of the recruiters believe that the deadlines are realistic and achievable (70\%), while only $26 \%$ believe the opposite. According to Zimmerman (1987) and De Winter (2013), the t-test can be used in cases when the samples are not the same size. The parameter values of burnout types for different opinions on deadlines, the significance of the t-test, absolute mean difference and the observed difference are given in Table 4 .

Table 4. Parameter values of burnout types for different marital status, the significance of the t-test, absolute mean difference and the observed difference

\begin{tabular}{|c|c|c|c|c|c|}
\hline Construct & Deadlines & Mean \pm SD & t-test & $\begin{array}{c}\text { Absolute mean } \\
\text { difference }\end{array}$ & Difference \\
\hline $\begin{array}{l}\text { Personal } \\
\text { burnout }\end{array}$ & $\begin{array}{l}\text { Realistic and } \\
\text { achievable } \\
\text { Unrealistic and } \\
\text { nonachievable }\end{array}$ & $\begin{array}{l}39.940 \pm 18.921 \\
54.861 \pm 24.440\end{array}$ & $-3.086^{* *}$ & 14.920 & $\begin{array}{l}\text { Realistic < } \\
\text { Unrealistic }\end{array}$ \\
\hline $\begin{array}{l}\text { Work- } \\
\text { related } \\
\text { burnout }\end{array}$ & $\begin{array}{l}\text { Realistic and } \\
\text { achievable } \\
\text { Unrealistic and } \\
\text { nonachievable }\end{array}$ & $\begin{array}{l}36.020 \pm 20.858 \\
51.785 \pm 21.010\end{array}$ & $-3.190^{* *}$ & 15.765 & $\begin{array}{l}\text { Realistic < } \\
\text { Unrealistic }\end{array}$ \\
\hline $\begin{array}{l}\text { Client- } \\
\text { related } \\
\text { burnout }\end{array}$ & $\begin{array}{l}\text { Realistic and } \\
\text { achievable } \\
\text { Unrealistic and } \\
\text { nonachievable }\end{array}$ & $\begin{array}{l}51.172 \pm 24.607 \\
70.139 \pm 24.607\end{array}$ & $-2.202^{* *}$ & 18.967 & $\begin{array}{l}\text { Realistic < } \\
\text { Unrealistic }\end{array}$ \\
\hline $\begin{array}{l}\text { Overall } \\
\text { burnout }\end{array}$ & $\begin{array}{l}\text { Realistic and } \\
\text { achievable } \\
\text { Unrealistic and } \\
\text { nonachievable }\end{array}$ & $\begin{array}{l}40.137 \pm 19.735 \\
56.320 \pm 22.250 \\
\end{array}$ & $-3.355^{* *}$ & 16.182 & $\begin{array}{l}\text { Realistic < } \\
\text { Unrealistic }\end{array}$ \\
\hline
\end{tabular}

The results indicate that for three types of burnout and the overall burnout there is a statistically significant difference between the recruiters who have realistic and unrealistic deadlines, supporting the Hypothesis 5. In all four cases, the recruiters who have unrealistic and non-achievable deadlines experience higher values of burnout. The greatest mean difference was for Client-related burnout (18.967) followed by Overall burnout (16.182). The statistically significant difference for Work-related and Client-related burnout could have been expected, but the result that the pressure of unrealistic deadlines has an important impact on Personal burnout is an interesting finding. Similar to the findings of Pawlowski et 
al. (2004) and Sethi et al. (1999), we can conclude that the work pressure manifested through deadlines has an impact not only on work activities, but also on personal relations.

To explore the effect of work pressure on burnout we used the Spearman's correlation coefficient between the Work pressure indicator and different types of burnout. The Spearman's correlation coefficient was used as we observed the correlation between a scale and ordinal variable, and Gardner and Martin (2007) and Jamieson (2004) showed that in case of tests which involve Likert scale non-parametric tests yield better results. As presented in Table 5, the obtained correlation coefficients range from 0.254 (Work-related burnout) to 0.330 (Client-related burnout). We can conclude that Hypothesis 6 is supported as observed work pressure has a statistically significant impact on the development of burnout, whereas it has a slightly stronger impact on the Client-related burnout than the other two types of burnout and overall burnout. As all correlation coefficients are positive, we can observe that the increased work pressure increases burnout. The findings are aligned with the findings of Maslach and Jackson (1985) and Constable and Russell (1986) who found that work pressure was strongly associated with employee burnout.

Table 5. Spearman's correlation coefficient between Work pressure and burnout

\begin{tabular}{lcccc}
\hline Construct & $\begin{array}{c}\text { Personal } \\
\text { burnout }\end{array}$ & $\begin{array}{c}\text { Work-related } \\
\text { burnout }\end{array}$ & $\begin{array}{c}\text { Client-related } \\
\text { burnout }\end{array}$ & $\begin{array}{c}\text { Overall } \\
\text { burnout }\end{array}$ \\
\hline Work pressure & $0.316^{* *}$ & $0.254^{*}$ & $0.330^{*}$ & $0.308^{* *}$ \\
\hline \multicolumn{5}{c}{${ }^{* *} p<0.01,{ }^{*} \mathrm{p}<0.05$} \\
\end{tabular}

\section{CONCLUSION AND RECOMMENDATIONS FOR FURTHER RESEARCH}

The finding of this study that Serbian recruiters sometimes face burnout syndrome leads us to believe that recruiter burnout should be treated all the same. Due to the fact that age has no statistical significance on the presence of burnout, burnout awareness and prevention programmes should be conducted for all age groups equally. Another valuable finding of the study is that work experience influences burnout of recruiters, which implies that burnout prevention trainings should be more often targeted to more experienced workers regardless of their age. They could also be interviewed more frequently in the attempt to check their levels and potential risk factors for burnout development, and more attention should be paid both from supervisors and HR department in this regard. It is also a recommendation for further research to examine what factors contribute to the positive correlation between burnout and work experience among recruiters, as well as to determine whether this correlation is different in 
different countries. In addition, since employees who are married or in a relationship showed lower risk of developing burnout, those individuals who are single should gain more support from the company, including supervisors, HR department and their colleges. Thus, they will be able to combat everyday work stress more easily and with a greater sense of safety. Despite the fact that the data on marital conflicts and the female perception of their family roles were not included in this study, they should not be neglected in the burnout prediction in general and should be a subject of another research. As both unrealistic deadlines and work pressure were found to affect recruiter burnout, companies should pay more attention to organizing work better in order to provide more realistic deadlines for recruiters, as well as attempt to reduce pressure to accomplish the goals set in a short period of time. HR managers should also engage in developing programmes that will focus on retaining employees (Slavković, Babić \& Stojanović Aleksić, 2015) to prevent recruiters' turnover.

Having in mind that burnout syndrome among recruiters occurs to some extent, other variables, like companies' factors, should also be investigated in order to understand whether they could influence the risk of burnout, such as working conditions or supervisors and colleagues support. Nevertheless, it is an encouraging datum that recruiters show a lower level of burnout than other professions, and good practices and policies their companies provide to them should be examined more closely and transferred to other industries whose employees suffer more dramatically from this omnipresent, modern-day disorder.

Another possible future direction of study could be the application of more advanced statistical multivariate analysis. For example, factor analysis could be employed to additionally check the grouping of the variables related to burnout. Also, structural equation model modelling (SEM) could be conducted to investigate the effect of control variables on specific burnout dimensions. One of the limitations of the study which could be tackled in the future research is the sample size. Namely, the research could be extended in the countries in the region.

\section{REFERENCES}

Ahola, K., Honkonen, T., Isometsä, E., Kalimo, R., Nykyri, E., Koskinen, S., Lönnqvist, J. (2006). Burnout in the general population. Social Psychiatry and Psychiatric Epidemiology, 41(1), 11-17.

Ahola, K., Honkonen, T., Virtanen, M., Aromaa, A., \& Lönnqvist, J. (2008). Burnout in Relation to Age in the Adult Working Population. Journal of Occupational Health, 50(4), 362-365.

Antoniou, A.-S., Polychroni, F. \& Vlachakis, A.-N. (2006). Gender and age differences in occupational stress and professional burnout between primary and high-school teachers in Greece. Journal of Managerial Psychology, 21(7), 682-690. 
Berry, M. (2008, July 28). Recruitment consultants are most stressed employees in UK. Retrieved from https://www.personneltoday.com/hr/recruitment-consultantsare-most-stressed-employees-in-uk/

Breaugh, J.A. \& Starke, M. (2000). Research on employee recruitment: so many studies, so many remaining questions. Journal of Management, 26 (3), 405-434.

Brewer, E.W. \& Shapard, L. (2004). Employee Burnout: A Meta-Analysis of the Relationship between Age or Years of Experience. Human Resource Development Review, 3(2), 102-123.

Byrne, B.M. (1991). Burnout: investigating the impact of background variables for elementary, intermediate, secondary, and university educators. Teaching and Teacher Education, 7, 197-209.

Cronbach, L. J. (1951). Coefficient alpha and the internal structure of tests. Psychometrika, 16(3), 297-334. https://doi.org/10.1007/BF02310555

Constable, J. F. \& Russell, D. W. (1986). The Effect of Social Support and the Work Environment upon Burnout among Nurses. Journal of Human Stress, 12(1), $20-26$.

Day, R. W. \& Quinn, G. P. (1989). Comparisons of treatments after an analysis of variance in ecology. Ecological monographs, 59(4), 433-463.

De Winter, J. C. (2013). Using the Student's t-test with extremely small sample sizes. Practical Assessment, Research \& Evaluation, 18(10). 1-12.

Foreman, M.H. (1996). The relationship between burnout and depression subtypes among clergy (Unpublished doctoral dissertation). United States International University, San Diego, CA.

Freudenberger, H. (1974). Staff Burnout. Journal of Social Issues, 30, 159-165.

http://dx.doi.org/10.1111/j.1540-4560.1974.tb00706.x

Greenglass, E. R. \& Burke, R. J. (1988). Work and family precursors of burnout in teachers: Sex differences. Sex Roles, 18(3-4), 215-229.

Ivančević, S. \& Kiković, G. (2017). Procena rizika za nastanak sindroma izgaranja kod nastavnika u osnovnoj školi: Zbornik rezimea „Dani defektologa 2017”. Novi Sad, Srbija ISBN 978-86-84765-51-4

Ivančević, S., Vaci, A. Nišić, A. (2016). Sindrom izgaranja na radnom mestu: Zbornik radova prve međunarodne stručno-naučne konferencije „Novi izazovi u edukaciji”. Čatež, Slovenija. ISBN 978-86-88125-22-2

Kristensen, T.S., Borritz, M., Villadsen, E. \& Christensen, K.B. (2005). The Copenhagen burnout inventory: a new tool for the assessment of burnout. Work \& Stress, 19(3), 192-207.

Lievens, F., van Dam, K. \& Anderson, N. (2002). Recent trends and challenges in personnel selection. Personnel Review, 31(5), 580-601, https://doi.org/10.1108/ 00483480210438771

Maslach, C. (1978). The client role in staff burn-out. Journal of Social Issues, 34(4), 111-124.

Maslach, C. (1982) Burnout: The Cost of Caring. Englewood Cliffs, NJ: Prentice-Hall.

Maslach, C., \& Jackson, S. E. (1985). The role of sex and family variables in burnout. Sex Roles, 12(7-8), 837-851.

Maslach, C. \& Jackson, S.E. (1986). Maslach Burnout Inventory Manual. Palo Alto, CA: Consulting Psychologists Press.

Maslach, C., Schaufeli, W. B. \& Leiter, M. P. (2001). Job Burnout. Annual Review of Psychology, 52(1), 397-422.

Melanthiou, Y., Pavlou, F. \& Constantinou, E. (2015). The use of social network sites as an e-recruitment tool. Journal of Transnational Management, 20 (1), 31-49.

Oh, H. \& Pizam, A. (2008). Handbook of Hospitality Marketing Management. Oxford, UK: Elsevier. 
Olson, J. E., Hanson Frieze, I., \& Good, D. C. (1987). The effects of job type and industry on the income of male and female MBAs. The Journal of Human Resources, 22(4), 532-541.

Pawlowski, S., Kaganer, E. \& Cater III, J. (2004). Mapping perceptions of burnout in the information technology profession: A study using social representations theory. ICIS 2004 Proceedings, Paper 73. Retrieved from http://aisel.aisnet.org/ icis $2004 / 73$

Peterson, R. A. (1994). A Meta-Analysis of Cronbach's Coefficient Alpha. Journal of Consumer Research, 21(2), 381-391. https://doi.org/10.1086/209405

Torrington, D., Hall, L. \& Taylor, S. (2011). Human Resource Management. London, UK: Prentice Hall.

Savage, G. (2013, July 9). This is why recruiters 'burn-out', [Blog post]. Retrieved from https://recruitingblogs.com/profiles/blogs/this-is-why-recruiters-burn-out

Savicki,V. \& Cooley, E.J. (1982). Implications of Burnout Research and Theory for Counselor Educators. Journal of Counselling and Development, 60(7), 415419. https://doi.org/10.1002/j.2164-4918.1982.tb00789.x

Schaufeli, W. B., Maassen, G. H., Bakker, A. B. \& Sixma, H. J. (2011). Stability and change in burnout: a 10-year follow-up study among primary carephysicians. Journal of Occupational and Organizational Psychology, 84, 248-267.

Sethi, V., Barrier, T., \& King, R. C. (1999). An Examination of the Correlates of Burnout in Information Systems Professionals. Information Resources Management Journal (IRMJ), 12(3), 5-13.

Slavković, M., Babić, V. \& Stojanović Aleksić, V. (2015). Talent Management: Opportunities and Limitations for Serbian Organizations. Teme - Journal for Social Sciences, XXXIX (2), 361-379.

Sorgaard, K.W., Ryan, P., Hill, R. \& Dawson, I. (2007). Sources of stress and burnout in acute psychiatric care: inpatient vs community staff. Social Psychiatry and Psychiatric Epidemiology, 42(10), 794-802.

Tavakol, M., \& Dennick, R. (2011). Making sense of Cronbach's alpha. International Journal of Medical Education, 2, 53-55. https://doi.org/10.5116/ijme.4dfb.8dfd

Trajković, T., Ivanović, T. \& Ivančević, S. (2019). Sindrom izgaranja kod zaposlenih na televiziji. Book of Proceedings of 14th International Conference Risk And Safety Engineering. Kopaonik, Srbija. ISBN 978-86-6211-116-6

Weeks, J. (2017). Why Recruiting is a High Turnover Industry. Retrieved from https://hr.sparkhire.com/staffing-industry/why-recruiting-is-a-high-turnoverindustry/

Zoromski, J. (2007, September 7). Recruiters Are at Risk of Burnout. Retrieved from https://www.ere.net/recruiters-are-at-risk-of-burnout/

Zimmerman, D. W. (1987). Comparative Power of Student t-test and Mann-Whitney U Test for Unequal Sample Sizes and Variances. The Journal of Experimental Education, 55(3), 171-174. doi: 10.1080/00220973.1987.10806451 


\title{
ДА ЛИ СЕ РЕГРУТЕРИ У СРБИЈИ СУОЧАВАЈУ СА СИНДРОМОМ ИЗГАРАЫА? УТИЦАЈ ДЕМОГРАФСКИХ ФАКТОРА, РОКОВА И ПРИТИСКА НА ПОСЛУ НА ПОЈАВУ ИЗГАРАҢА
}

\author{
Татјана Ивановић $^{\mathbf{1}}$, Соња Иванчевић ${ }^{\mathbf{1}}$, Тања Трајковић $^{\mathbf{2}}$, Милица Маричић \\ ${ }^{1}$ Универзитет у Београду, Факултет организационих наука, Београд, \\ Република Србија \\ ${ }^{2} \mathrm{ICL}$ Services and Solutions, Београд, Република Србија
}

\section{Резиме}

Од средине седамдесетих година, када је термин синдром изгарања уведен у психологију, стално се повећава број истраживања на тему синдрома изгарања. Скорија истраживања су показала да се синдром изгарања не јавља само у помажућим професијама, како се раније сматрало, већ и у другим занимањима. У овом раду се истражује синдром изгарања код регрутера, при чему се имају у виду специфичности ове професије и бројни изазови са којима се регрутери свакодневно сусрећу у погледу количине посла и притиска на послу. Стратешки и практично гледано, регрутовање представља једну од најзначајнијих функција менаџмента људских ресурса. Имајући у виду да ово истраживање представља прво истраживање синдрома изгарања код регрутера у Србији, за анализу су одабране неке од најчешће испитиваних варијабли. Емпиријско истраживање је спроведено 2019. године путем онлајнупитника који је дистрибуиран мејлом. За статистичку анализу коришћен је SPSS 22. Узорак се сатојао од 100 регрутера. С обзиром на то да компаније у Србији најчешће немају позицију регрутера или, ако је имају, обично имају једног или два регрутера, може се сматрати да укупан број од 100 испитаника представља репрезентативан узорак за Србију. Копенхаген-упитник (CBI) коришћен је за мерење синдрома изгарања код регрутера. Резултати су показали да изгарање у вези са клијентима има највећу средњу вредност $(55,496)$, а затим изгарање на личном нивоу $(42,875)$. Испитаници су имали најнижу средњу вредност за изгарање у вези са послом $(39,5)$. Средња вредност за укупно изгарање износи 43,685, што значи да се испитаници понекад суочавају са синдромом изгарања. Пронађено је да следеће варијабле имају утицај на могућност појаве синдрома изгарања код регрутера - радно искуство, брачни статус, рокови и притисак на послу. Највећи ризик од суочавања са синдромом изгарања носе регрутери са више искуства у струци, који нису у браку, који имају нереалне рокове и велики притисак на послу. Резултати овог истраживања, који су показали да се регрутери у Србији повремено суочавају са синдромом изгарања, подстакли су нас да верујемо да је потребно вршити превенцију и лечење овог поремећаја. Из овог разлога, у раду су дате смернице за осмишљавање ефективних стратегија за превенцију синдрома изгарања код регрутера које имају за циљ да спрече флуктуацију регрутера и да сачувају њихово ментално здавље. 